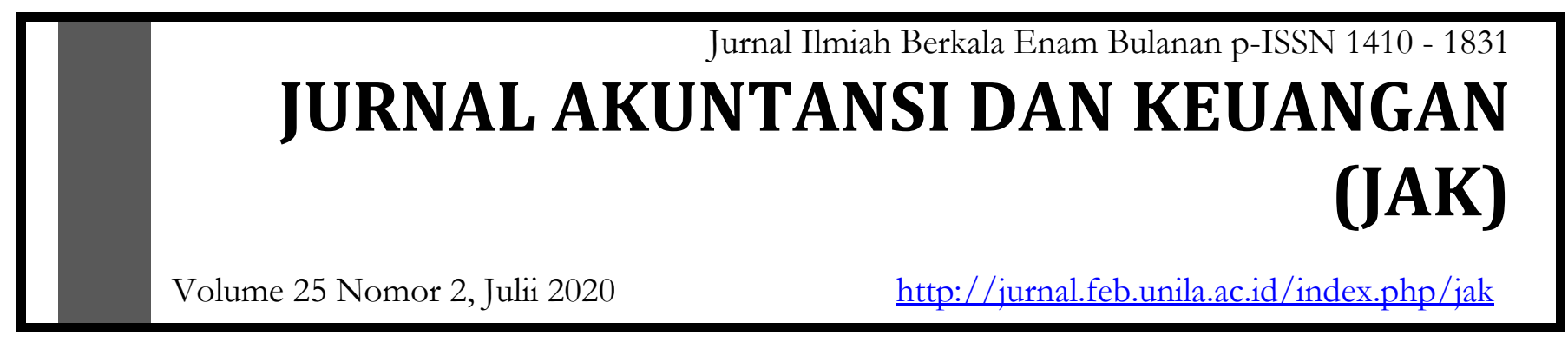

\title{
PENGARUH PENERAPAN FINTECH, DANA PIHAK KETIGA, DAN EFISIENSI OPERASIONAL TERHADAP PROFITABILITAS
}

\author{
Ilham Suwanderi ${ }^{1}$, Lindrianasari ${ }^{2}$, Niken Kusumawardani ${ }^{3}$ \\ ${ }^{1}$ Fakultas Ekonomi dan Bisnis, Universitas Lampung \\ 2 Fakultas Ekonomi dan Bisnis, Universitas Lampung \\ 3 Fakultas Ekonomi dan Bisnis, Universitas Lampung
}

\section{Informasi Naskah}

Update Naskah:

Update Naskah:

Dikumpulkan: 4 April 2020

Diterima: 20 Mei 2020

Terbit/Dicetak: 17 Juli 2020

\section{Keywords:}

Financial Technology, Third Party Funds, Operational Efficiency, Profitability

\section{$\underline{\text { Abstract }}$}

Profitability has information to determine the level of profit that the company recieves in a certain period of time and the productivity of the use of comapny's funds, both loan capital and own capital, which can be used by investors and potential investors as a basis for making decision in investing. This studi aims to determine the extent to which the application of fintech affects the profitability, finding out to what extent third party funds affects the profitability, and to find out to what extent does operational efficiency affects profitability of Banking Companies listed in IDX in year 2014-2018. Samples in this research is chosen using purposive sampling method, and obtained 102 samples. The result shows that the application of financial technology, third party funds, and operational efficiency has a positive and significant effect on profitability. 


\section{A. PENDAHULUAN}

Laporan keuangan merupakan salah satu sumber informasi keuangan perusahaan yang dihasilkan sebagai wujud pertanggungjawaban manajemen atas pengelolaan sumber daya perusahaan kepada pihakpihak yang berkepentingan terhadap suatu perusahaan. Tujuan penyusunan laporan keuangan adalah untuk menyediakan informasi yang berguna dalam proses pengambilan keputusan. Berdasarkan PSAK No.1, tujuan penyusunan laporan keuangan adalah untuk menyediakan informasi yang menyangkut posisi keuangan, kinerja, dan arus kas perusahaan yang bermanfaat bagi sejumlah besar pemakai dalam pengambilan keputusan ekonomi. Manajemen dalam menyajikan laporan keuangan harus menggungkapkan informasi yang sebenarnya, untuk menyakinkan bahwa laporan keuangan telah disajikan dengan benar, maka diperlukan pihak eksternal untuk menyakinkan pihak yang berkepentingan. Pihak yang dinilai independen dalam hal ini adalah auditor. Auditor mulai diminta pertanggungjawabannya untuk mengungkapkan informasi yang tidak sebatas hanya pada pada hal-hal yang ditampakkan dalam laporan keuangan tetapi juga harus mengungkapkan informasi seperti eksistensi dan kontinuitas entitas. Auditor diharapkan tidak hanya memeriksa laporan keuangan atau mendeteksi kecurangan tetapi juga sanggup memprediksi dan menilai kemampuan perusahaan dalam melangsungkan hidupnya. Good Corporate Governance menjadi salah satu kunci sukses perusahaan untuk tumbuh dan menguntungkan dalam jangka panjang, sekaligus memenangkan persaingan bisnis global terutama bagi perusahaan yang telah mampu berkembang sekaligus menjadi terbuka. Good Corporate Governance merupakan sistem mengenai bagaimana suatu organisasi dikelola dan dikendalikan. Sistem governance antara lain mengatur mekanisme pengambilan keputusan pada tingkat atas organisasi. Good Corporate Governance mengatur hubungan antar dewan komisaris, direksi, dan manjemen perusahaan agar terjadi keseimbangan dalam pengelolaan organisasi.

Kepemilikan manajerial adalah salah satu bentuk mekanisme Good Corporate Governance yang bisa menyamakan kepentingan pemilik dan pengelola perusahaan. Besar kecilnya jumlah kepemilikan saham manajerial dalam perusahaan dapat mengindikasikan adanya kesamaan (congruance) kepentingan antara manajemen dengan pemegang saham (Faizal, 2004). Dalam penelitian Petronila (2007) menyatakan keberadaan komisaris independen mempengaruhi auditor dalam pemberian opini audit going concern dikarenakan keberadaan komisaris independen dapat menyelaraskan proses pengambilan keputusan yang terkait dengan perlindungan terhadap pemegang saham minoritas dan stakeholder.

Kasus PT Asia Natural Resources Tbk yang mendapatkan opini audit going concern yang pada akhirnya delisiting dari Bursa Efek Indonesia pada tahun 2014. Hal ini dikarenakan perusahaan tersebut tidak bisa memenuhi ketentuan bursa dan sahamnya disuspensi sejak 22 Mei 2014. Perseroan juga punya tunggakan Rp 110 juta atas denda BEI. Kinerja keuangan perseroan juga makin buruk. Pada semester I2014 perseroan tidak membukukan penjualan sama sekali sehingga menderita kerugian hingga Rp 357,33 miliar (finance.detik.com). Fenomena tersebut kemudian memunculkan pertanyaan mengenai alasan perusahaan yang memperoleh opini wajar tanpa pengecualian (unqualified opinion) justru tidak dapat mempertahankan kelangsungan usahanya. Di dalam peraturan otoritas jasa keuangan nomor 29 /POJK.04/2016 tentang laporan tahunan emiten atau perusahaan publik dalam pasal 4 yang salah satu isinya adalah laporan keuangan telah di audit pada saat di terbitkan untuk publik. Serta untuk mekanisme corporate governance untuk perusahaan terbuka terdapat dalam undang-undang Republik Indonesia nomor 40 tahun 2007 tentang perseroan terbatas, yaitu isinya adalah beberapa unsur-unsur good corporate 
governance. Sehingga hal ini menguatkan bahwa perusahaan publik harus menerapkan mekanisme corporate governance di perusahaan-perusahaan publik untuk kelangsungan hidup suatu perusahaan.

Mengukur opini audit going concern adalah Kepemilikan manjerial menurut Sofyaningsih dan Hardiningsih (2011) semakin besar kepemilikan saham oleh manajemen maka semakin kuat kecenderungan manajemen untuk mengoptimalkan penggunaan sumber daya sehingga akan mempengaruhi kinerja berpengaruh positif perusahaan akan tetapi penelitian tersebut sejalan dengan Penelitian Petronila (2007) menemukan bukti bahwa ada pengaruh positif terhadap penerimaan opini audit going concern namun kedua penelitian tersebut tidak sejalan dengan penelitian yang dilakukan oleh Penelitian Iskandar et al (2011) adanya hubungan berbanding terbalik antara kepemilikan manajerial dengan opini going concern berpengaruh negatif. Selain itu, proksi yang dapat digunakan untuk mengukur opini going concern adalah Kepemilikan Institusional menurut hasil Penelitian Riyanda dan Indriani (2013) yang menunjukkan bahwa kepemilikan institusional tidak berpengaruh terhadap opini going concern. Pada penelitian ini juga di dukung dengan hasil penelitian Iskandar et al (2011) yang mengungkapkan kepemilikan institusional berhubungan negatif dengan opini going concern namun kedua penelitian tersebut berbeda dengan penelitian Shleifer dan Vishny (1999) dalam Wiranta dan Nugrahanti (2013) bahwa kepemilikan institusional memiliki insentif untuk memantau pengambilan keputusan perusahaan. Hal ini akan berpengaruh positif terhadap opini going concern.

\section{B. LANDASAN TEORI DAN PENGEMBANGAN HIPOTESIS}

Teori agensi adalah teori yang menyatakan adanya hubungan kerja antara pihak yang memberi wewenang (prinsipal) yaitu investor dengan pihak yang menerima wewenang (agensi) yaitu manajer, dalam bentuk kontrak kerja sama yang disebut "nexus of contract” Jensen dan Meckling (1976). Teori agensi mengasumsikan bahwa semua individu bertindak atas kepentingan mereka sendiri. Pemegang saham sebagai principal diasumsikan hanya tertarik kepada hasil keuangan yang bertambah atau investasi mereka di dalam perusahaan. Sedangkan para agen diasumsikan menerima kepuasan berupa kompensasi keuangan dan syarat-syarat yang menyertai dalam hubungan tersebut.

Jensen dan Meckling (1976) menjelaskan bahwa hubungan keagenan merupakan suatu kontrak dimana satu orang atau lebih (prinsipal) melibatkan orang lain (agen) untuk melakukan suatu jasa atas nama. prinsipal serta memberi wewenang kepada agen untuk membuat keputusan yang terbaik bagi prinsipal. Pendesainan kontrak yang tepat untuk menyelaraskan kepentingan manajemen dan pemilik dalam hal konflik kepentingan tersebut merupakan inti dari agency theory.

\section{Pengaruh Kepemilikan Manajerial terhadap Opini Going Concern}

Kepemilikan manajerial perusahaan diharapkan dapat meningkatkan nilai perusahaaan sehingga potensi kesulitan keuangan dapat dihindari. Apabila nilai perusahaan meningkat opini audit going concern pada auditor akan mengeluarkan opini yang baik maka dapat meningkatkan nama baik bagi auditor itu sendiri dengan begitu akan meningkatkan nilai saham yang ada dan investor mayoritas, minoritas maupun investor baru akan meningkat dan berdatangan. Hal tersebut sesuai dengan hasil penelitian yang dikemukakan oleh Adjani dan Rahardja (2013) yang menunjukkan bahwa kepemilikan manajerial berpengaruh signifikan terhadap kemungkinan pemberian opini going concern oleh auditor independen. Semakin besar kepemilikan manajerial maka kemungkinan auditor memberikan opini going concern semakin kecil. Pada penelitian ini juga didukung oleh Parker et al (2005) dalam Petronila (2007) 
menunjukkan bahwa hubungan antara kepemilikan manajerial dengan opini going concern berbanding terbalik.

Dalam penelitian Linoputri (2010), Iskandar et al (2011), dan Adjani (2013) yang menunjukkan bahwa kepemilikan manajerial memiliki pengaruh positif terhadap opini going concern. Linoputri (2010), Iskandar et al (2011), dan Adjani (2013) dalam penelitiannya menunjukkan bahwa semakin besar kepemilikan manajerial maka semakin kecil kemungkinan auditor memberikan opini going concern pada perusahaan. Semakin besar proporsi kepemilikan manajerial salam suatu perusahaan maka kemungkinan kecil kasus manipulasi data keuangan seperti manajemen laba akan mengganggu kelangsungan hidup perusahaan dalam penelitian Herawaty (2008). Sehingga semakin besar saham yang dimiliki manajemen laba maka semakin rendah.

Hasil penelitian yang sama juga dikemukakan oleh Jensen dan Meckling (1976) dalam Mada (2013) mengemukakan bahwa kepemilikan manjerial dapat menyelaraskan kepentingan manajer dengan pemegang saham sehingga berhasil menjadi mekanisme yang dapat mengurangi masalah keagenan antara manajer dengan pemilik. Hal ini dikarenakan adanya kepemilikan manajerial yang dimiliki oleh manajerial berarti manajer juga bertindak sebagai principal sehingga dapat tercipta keselarasan antara tujuan agen dan principal yang juga merupakan dirinya sendiri. Ardianingsih dan Ardiyani (2010) menemukan ada pengaruh kepemilikan manajerial terhadap kinerja perusahaan. Hasil penelitian yang sama juga dikemukakan oleh Petronila (2007) menemukan bukti bahwa ada pengaruh signifikan kepemilikan manajerial terhadap opini going concern. Berdasarkan penjelasan tersebut, maka penelitian ini mengajukan hipotesis sebagai berikut:

\section{H1: Kepemilikan manajerial berpengaruh positif terhadap Opini Going Concern}

\section{Pengaruh Kepemilikan Institusional terhadap Opini Going Concern}

Kepemilikan institusional merupakan kepemilikan oleh pihak di luar perusahaan. Apabila perusahaan mendapatkan hasil yang baik maka nilai perusahaan akan meningkat, kemudian akan timbul goodwill dan opini audit going concern pada auditor akan mengeluarkan opini yang baik maka dapat meningkatkan nama baik bagi perusahaan dan auditor itu sendiri.

Namun sebaliknya apabila hasil yang dikeluarkan buruk maka nila i perusahaan akan turun dan akan berpengaruh kepada para pemegang saham institusi yang nantinya akan hilang atau mencabut kesepakatannya dengan perusahaan tersebut karena opini yang dikeluarkan auditor buruk dan mengakibatkan kerugian untuk para investor tersebut. Keberadaan auditor dan kepemilikan institusional dalam perusahaan dapat menjadi pengawas yang efektif bagi perusahaan. Hal tersebut sesuai dengan hasil penelitian Haruman (2008) dalam Ariyanto dan Setyorini (2013) bahwa kepemilikan institusional berpengaruh negatif terhadap opini going concern. Kemudian pada penelitian Utami (2009) menunjukkan bahwa semakin besar kepemilikan institusional maka efisien pemanfaatan aktiva perusahaan dan dapat diharapkan juga dapat bertindak sebagai pencegahan terhadap pemborosan yang dilakukan oleh manajemen. Semakin besar presentase kepemilikan maka akan semakin besar dorongan untuk mengawasi manajemen dan kinerjanya sehingga dapat mengurangi potensi opini audit going concern.

Hasil penelitian yang sama juga dikemukakan oleh Riyanda dan Indriani (2013) yang menunjukkan bahwa kepemilikan institusional berpengaruh negatif terhadap opini going concern. Dalam penelitian Widarjo et al. (2010) menjelaskan bahwa kondisi dimana institusi memiliki saham dalam suatu perusahaan. 
Institusi tersebut dapat berupa institusi pemerintah, institusi swasta, domestik maupun asing. Kepemilikan institusional dianggap lebih efektif dalam mengurangi masalah yang ditimbulkan karena teori keagenan, karena sebuah institusi dianggap lebih mampu dalam mengontrol manajemen dalam mengelola perusahaan melalui proses monitoring yang efektif. Berdasarkan penelitian tersebut, maka penelitian ini mengajukan hipotesis sebagai berikut:

\section{H2: Kepemilikan Institusional berpengaruh negatif terhadap Opini Going Concern}

\section{Pengaruh Proporsi Dewan Komisaris Independen terhadap Opini Going Concern}

Komisaris independen bertujuan untuk menyeimbangkan dalam pengambilan keputusan khususnya dalam rangka perlindungan terhadap pemegang saham minoritas dan pihak-pihak lain yang terkait. Apabila keputusan yang diambil benar maka opini yang dikeluarkan oleh auditor akan baik maka investor baik mayoritas ataupun minoritas akan merasa aman dengan menaruh saham di perusahaan tersebut apabila sebaliknya maka investor akan mencabut kesepakatan dan dapat melepaskan saham tersebut baik pemegang saham mayoritas maupun minoritas dan akan menurunkan nilai pada perusahaan tersebut.

Hasil penelitian tersebut sama dengan hasil penelitian yang dikemukakan oleh penelitian Setiawan (2011) mengungkapkan adanya pengaruh negatif proporsi komisaris independen terhadap opini going concern pada perusahaan, hal tersebut sama dengan hasil penelitian Fama dan Jensen (1983) dalam Ujiyantho dan Pramuka (2007) menyatakan bahwa proporsi dewan komisaris independen dapat bertindak sebagai penengah dalam perselisihan yang terjadi antara para manajer internal dan mengawasi kebijakan manajemen serta memberikan nasihat kepada manajemen maka proporsi dewan komisaris independen berpengaruh negatif terhadap opini going concern. Berdasarkan penjelasan tersebut, maka penelitian ini mengajukan hipotesis sebagai berikut:

\section{H3: Proporsi Dewan Komisaris Independen berpengaruh negatif terhadap Opini Going Concern.}

\section{METODE PENELITIAN}

\section{Populasi dan Sampel}

Populasi dalam penelitian ini adalah perusahaan manufaktur yang terdaftar di Bursa Efek Indonesia pada tahun 2014-2018. Pemilihan sampel menggunakan purposive sampling sehingga diperoleh sampel perusahaan.

\section{Jenis dan Sumber Data}

Jenis data yang dikumpulkan dalam penelitian ini adalah data sekunder, dimana data berupa annual report dan laporan keuangan perusahaan yang terdaftar di BEI pada periode 2014-2018. Data tersebut dapat diperoleh dengan mengakses situs web www.idx.co.iddan situs perusahaan yang bersangkutan.

\section{Metode Analisis Data}

Sesuai dengan tujuan dibuatnya penelitian ini, yaitu untuk menganalisis pengaruh good corporate governance terhadap opini going concern pada perusahaan manufaktur industri maka metode yang digunakan untuk menguji hipotesis adalah regresi logistik dengan bantuan Statistical Package for the Social Sciences (SPSS) 25. Statistik deskriptif juga digunakan untuk memberikan gambaran mengenai variabelvariabel dalam penelitian ini. Model yang digunakan dalam penelitian ini adalah sebagai berikut: 


$$
\mathrm{OGC}=\alpha+\beta 1 \mathrm{KM}+\beta 2 \mathrm{KI}+\beta 3 \mathrm{PDKI}+\varepsilon
$$

Keterangan :

OGC = Opini going concern yang diukur dengan variabel dummy yaitu bernilai 0 jika perusahaan diaudit mendapati opini wajar dengan pengecualian dan bernilai 1 jika perusahaan tidak medepati opini going concern

$\alpha \quad=$ Konstanta

$\mathrm{KM}=$ Kepemilikan manajerial

KI $=$ Kepemilikaninstitusional

PDKI = Proporsi dewan komisarisindependen

\section{Variabel Penelitian}

Variabel dependen merupakan variabel yang begantung atau dipengaruhi oleh variabel-variabel lain yang bebas. Variabel yang digunakan dalam penelitian ini adalah opini going concern. Variabel dependen diukur menggunakan variabel dummy, nilai 1 apabila perusahaan mendapati opini going concern dan nilai 0 apabila perusahaan tidak mendapati opini going concern.

Variabel independen merupakan variabel bebas yang bisa mempengaruhi atau menjelaskan variabel dependen. Variabel yang digunakan dalam penelitian ini adalah kepemilikan manajerial, kepemilikan institusional, dan proporsi dewan komisarisin dependen.

\section{ANALISIS DAN PEMBAHASAN}

Berdasarkan pengumpulan data menggunakan metode purposive sampling, maka diperoleh 50 data yang dapat digunakan dalam penelitian ini. Berikut Tabel 1 yang merupakan ringkasan pengumpulan sampel:

Tabel 1. Tahapan Seleksi sampel dengan kriteria

\begin{tabular}{|l|c|}
\hline & Jumlah \\
\hline Jumlah perusahaan industri manufaktur yang terdaftar di BEI & 120 \\
\hline Perusahaan yang tidak menerbitkan Annual Report di antara tahun 2014-2018 & 65 \\
\hline Jumlah perusahaan yang delisting dari BEI selama periode pengamatan & 5 \\
\hline Akumulasi & 50 \\
\hline Jumlah sampel perusahaan industri manufaktur yang dapat digunakan & 250 \\
\hline Outlier & 7 \\
\hline Akumulasi sampel perusahaan industri manufaktur yang dapat digunakan & 243 \\
\hline
\end{tabular}

Sumber: Data sekunder yang di olah

\section{Analisis Statistik Deskriptif}

Analisis deskriptif merupakan metode dimana semua data yang berhubungan dengan penelitian dikumpulkan dan dikelompokkan untuk kemudian dianalisis dan diinterpretasikan secara objektif dengan membandingkan nilai minimum, nilai maksimum, rata-rata, dan standar deviasi dari sampel. Nilai minimum, nilai maksimum, dan standar deviasi menggambarkan persebaran data, dimana data yang memiliki standar deviasi yang semakin besar menggambarkan bahwa data tersebut semakin menyebar. Berikut ini Tabel 2 yang merupakan analisis deskriptif untuk variabel yang digunakan dalam penelitian ini: 
Tabel 2. Hasil Uji Statistik Deskriptif

\begin{tabular}{|c|c|c|c|c|c|}
\hline & N & Minimum & Maximum & Mean & Std.Deviation \\
\hline GC & 243 & 0 & 1 &, 32 &, 466 \\
\hline KM & 243 &, 00 & 95,15 & 5,9008 & 13,03723 \\
\hline KI & 243 &, 20 & 76,66 & 8,6482 & 6,61899 \\
\hline PDKI & 243 &, 40 & 1,00 &, 6294 &, 09013 \\
\hline Valid N (listwise) & 243 & & & & \\
\hline
\end{tabular}

Sumber: Output SPSS

Berdasarkan Tabel 2, Hasil analisis menggunakan statistik deskriptif terhadap opini going concern (GC) menunjukkan nilai minimum sebesar 0 dan nilai maksimum sebesar 1 . Nilai rata-rata sebesar 0,32 artinya penelitian ini menggunakan $32 \%$ perusahaan yang mendapati opini going concern dan $68 \%$ perusahaan yang tidak mendapati opini going concern. Nilai standar deviasi yang diperoleh sebesar0,466. Kepemilikan manajerial (KM) menunjukkan nilai minimum sebesar 0 dan nilai maksimum sebesar 95,15. Artinya nilai maksimum sebesar 95,15\% dari jumlah saham beredar di perusahaan industry manufaktur pada periode pengamatan yang dimiliki manajerial, sisanya dimiliki oleh masyarakat dan institusiinstitusi.

Kemudian perusahaan yang mendapati saham kepemilikan manajerial paling besar adalah PT Pelangi Indah Canindo Tbk. Dengan nilai rata-rata diperoleh sebesar 5,9008 dan nilai standar deviasi diperoleh sebesar13,03723. Kepemilikan institusional (KI) menunjukkan nilai minimum sebesar 20\% dan nilai maksimum sebesar $100 \%$. Nilai minimum sebesar $20 \%$ artinya perusahaan yang mendapati saham minimum kepemilikan institusional diantaranya adalah PT Pelangi Indah Canindo Tbk dan nilai maksimum sebesar 100\% dipegang oleh beberapa perusahaan seperti PT HM Sampoerna Tbk, PT Keramika Indonesia Assosiasi Tbk, PT KALBE Tbk, PT Indomobil Sukses Internasional Tbk, PT BATA Tbk, dan PT Charoen Pokphand Indonesia Tbk, sedangkan sisanya dimiliki oleh masyarakat dan manajerial.

Dengan nilai rata-rata diperoleh sebesar 8,6482 dan nilai standar deviasi diperoleh sebesar 6,61899. Proporsi dewan komisaris independen (PDKI) menunjukkan nilai minimum sebesar $40 \%$ dan nilai maksimum sebesar 0,01\%. Artinya pada periode penelitian memiliki proporsi dewan komisaris independen sebanyak $40 \%$ dari jumlah dewan komisaris yang ada diperusahaan, hal ini kurang baik karena melebihi yang disyaratkan BEI yaitu sebesar 30\% dari jumlah komisaris. Nilai maksimum komisaris independen menunjukkan bahwa perusahaan industri manufaktur dalam periode penelitian memiliki proporsi komisaris independen yang rendah yaitu sebesar $0,01 \%$ dari jumlah dewan komisaris yang ada diperusahaan. Nilai rata-rata diperoleh sebesar 0,6294 dan nilai standar deviasi diperoleh sebesar 0,09013.

\section{Hasil Uji Kesesuaian Seluruh Model (Overall ModelFit)}

Pengujian dilakukan dengan membandingkan nilai -2 Log Likelihood (-2LL) pada awal (Block Number=0) dengan nilai -2 Log Likelihood (-2LL) pada akhir (Block Number=1). Nilai -2LL awal adalah 294,691. Setelah dimasukkan tiga variabel independen, maka nilai -2LL mengalami penurunan menjadi 291,713. Penurunan Likelikhood (-2LL) ini menunjukkan bahwa model regresi yang lebih baik atau dengan kata lain model yang dihipotesiskan fit dengan data. 
Tabel 3. Kesesuaian Seluruhan Model

Coefficient

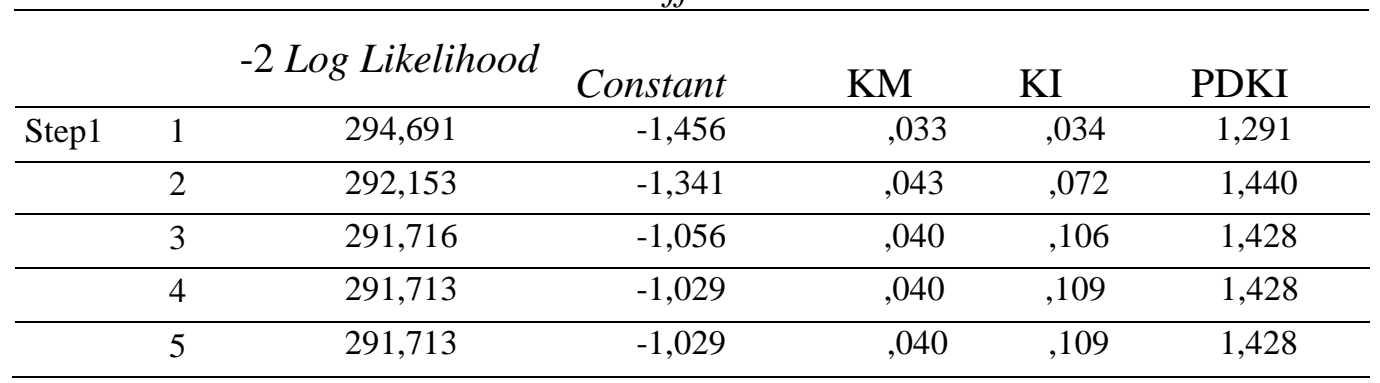

Sumber: Output SPSS

\section{Hasil Uji Koefisien Determinasi (Negelkerke RSquare)}

Besarnya nilai determinasi pada uji regresi logistik ditunjukkan oleh nilai Negelkerke $R$ Square. Nilai Negelkerke $R$ Square adalah sebesar 1,09 yang berarti variabel dependen dapat dijelaskan oleh variabel-varibel independen adalah sebesar 1,09\%, sedangkan sisanya sebesar 98,09\% dijelaskan oleh variabel- variabel lain di luar penelitian.

Tabel 4. Koefisien Determinasi

\begin{tabular}{|c|c|c|c|}
\hline Step & $\begin{array}{c}-2 \text { Log } \\
\text { likehood }\end{array}$ & $\begin{array}{c}\text { Cox \& Snell R } \\
\text { Square }\end{array}$ & $\begin{array}{c}\text { Nagelkerke R } \\
\text { Square }\end{array}$ \\
\hline 1 & $291,713^{\mathrm{a}}$ &, 078 &, 109 \\
\hline
\end{tabular}

Sumber: Output SPSS

\section{Hasil Uji Kelayakan Model Regresi}

Kelayakan model regresi dinilai dengan menggunakan Hosmer and Lameshow's Goodness of Fit Test. Pengujian menunjukkan nilai Chi Square sebesar 13,364 dengan signifikansi sebesar 1,00. Berdasarkan hasil tersebut, karena nilai signifikansi lebih besar dari 0,05, maka model dapat disimpulkan mampu memprediksi nilai observasinya atau model dapat diterima karena cocok dengan data observasinya.

Tabel 5. Kelayakan Model Regresi

\begin{tabular}{|c|l|c|c|}
\hline Step & Chi-Square & Df & Sig. \\
\hline 1 & 13,364 & 8 &, 100 \\
\hline
\end{tabular}

Sumber: Output SPSS

\section{Hasil MatriksKlasifikasi}

Matriks klasifikasi menunjukkan kekuatan prediksi dari model regresi untuk memprediksi kemungkinan perusahaan menerima opini goingconcern.

Tabel 6. Matriks Klasifikasi

\begin{tabular}{|c|c|c|c|c|c|}
\hline \multicolumn{6}{|c|}{ Predicted } \\
\hline & & GC & Percentage Correct & & \\
\hline \multicolumn{2}{|c|}{ Observed } & 0 & 1 & & \\
\hline \multirow[t]{2}{*}{ Step 0} & $\mathrm{GC}$ & 0 & 164 & 7 & 95,9 \\
\hline & & 1 & 164 & 15 & 19,0 \\
\hline \multicolumn{5}{|c|}{ Overall Percentage } & 71,6 \\
\hline
\end{tabular}

Sumber: Output SPSS

Kekuatan prediksi dari model regresi untuk memprediksi kemungkinan perusahaan menerima opini going concern adalah sebesar 19,0\%. Hal ini menunjukkan, dengan menggunakan model regresi 
yang digunakan terdapat 15 perusahaan yang diprediksi akan menerima opini going concern dari total 50 perusahaan. Kekuatan prediksi model perusahaan yang tidak menerima opini going concern adalah sebesar 95,9\% yang berarti bahwa dengan model regresi yang digunakan, ada sebanyak 35 perusahaan yang diprediksi tidak menerima opini going concern dari total 50 perusahaan. Dapat disimpulkan bahwa kekuatan prediksi dari model regresi sebesar $71,6 \%$.

\section{Hasil Regresi UjiLogistik}

Estimasi parameter dapat dilihat melalui koefisien regresi. Koefisien regresi dari tiap-tiap variabel yang diuji menunjukkan bentuk hubungan antara variabel yang satu dengan yang lainnya. Uji wald digunakan dalam pengujian hipotesis pada penelitian ini. Uji wald dilakukan dengan cara membandingkan antara nilai probabilitas (sig). Apabila terlihat angka signifikan lebih kecil terlihat 0,05 maka koefisien regresi adalah signifikan pada tingkat 5\%. Hal itu berarti $\mathrm{H} 0$ ditolak dan $\mathrm{H} 1$ diterima, yang berarti bahwa variabel bebas berpengaruh secara signifikan terhadap terjadinya variable terikat. Analisis uji regresi ini untuk menguji seberapa jauh semua variabel terikat. Hasil koefisien regresi dapat ditentukan dengan menggunakan nilai probabilitas (sig) pada Tabel7.

Tabel 7. Regresi Uji Logistik

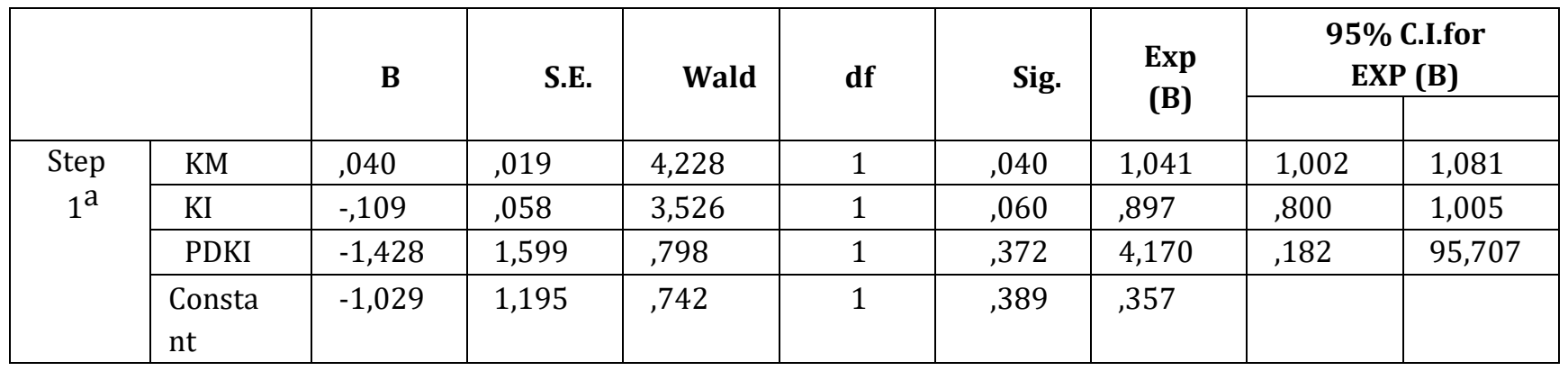

Sumber: Output SPSS

\section{Pengaruh Kepemilikan Manajerial (KM) terhadap Opini Going Concern(OGC)}

Berdasarkan pengujian yang telah dilakukan, hasil penelitian ini menunjukkan bahwa variabel kepemilikan manajerial menunjukkan koefisien regresi positif sebesar 0,04 dengan tingkat signifikansi sebesar 0,04 $(<0,05)$. Dengan demikian, hipotesis pertama (Ha1) terdukung yang artinya kepemilikan manajerial berpengaruh positif terhadap opini going concern. Berdasarkan nilai odds ratio, probabilitas perusahaan yang memiliki kinerja manajerial untuk mendapatkan opini going concern dari laporan opini yang dikeluarkan oleh auditor internal perusahaan adalah sebesar 1,081 dibandingkan dengan perusahaan yang memiliki rasio kepemilikan manajerial lebih rendah ataupun0.

Hasil penelitian ini sejalan dengan penelitian Petronila (2007) menunjukkan bahwa ada pengaruh signifikan kepemilikan manajerial terhadap opini going concern. Pada penelitian Parker et al (2005) dalam Petronila (2007) juga menjelaskan bahwa jika hubungan antara kepemilikan manajerial dengan opini going concern berbanding terbalik.

Hasil penelitian ini sejalan dengan Linoputri (2010), Iskandar et al (2011), dan Adjani (2013) yang menunjukkan bahwa kepemilikan manajerial memiliki pengaruh positif terhadap opini going concern. Linoputri (2010), Iskandar et al (2011), dan Adjani (2013) dalam penelitiannya menunjukkan bahwa semakin besar kepemilikan manajerial maka semakin kecil kemungkinan auditor memberikan opini going concern pada perusahaan. Semakin besar proporsi kepemilikan manajerial dalam suatu perusahaan maka 
kemungkinan kecil kasus manipulasi data keuangan seperti manajemen laba akan mengganggu kelangsungan hidup perusahaan dalam penelitian Herawaty (2008). Kemudian pada penelitian Ukago (2004) dalam Difa \& Suryono (2015) juga menjelaskan bahwa semakin besar jumlah saham yang dimiliki oleh pihak manajemen atas entitas, maka manejemen akan berupaya lebih besar untuk memenuhi kepuasan dan tujuan pemegang saham termasuk kepuasannya sendiri.

\section{Pengaruh Kepemilikan Institurional (KI) terhadap Opini Going Concern (OGC)}

Berdasarkan pengujian yang telah dilakukan, hasil penelitian ini menunjukkan koefisien regresi negatif sebesar 0,109 dengan tingkat signifikansi sebesar 0,06 (>0,05). Dengan demikian, hipotesis kedua (Ha3) tidak terdukung yang artinya proporsi dewan komisaris independen tidak berpengaruh signifikan terhadap opini going concern. Berdasarkan nilai odds ratio, probabilitas perusahaan yang memiliki proporsi dewan komisaris independen untuk mendapatkan opini going concern dari laporan opini yang dikeluarkan oleh auditor internal perusahaan adalah sebesar 1,005 dibandingkan dengan perusahaan yang memiliki rasio kepemilikan institusional lebih tinggi.

Hasil penelitian ini sejalan dengan penelitian Setiawan (2011) yang menunjukkan bahwa tidak ada pengaruh yang signifikan antara kepemilikan institusional terhadap opini going concern. Peneliti menduga penyebab tidak ditemukan adanya pengaruh yang signifikan kepemilikan institusional terhadap opini going concern menunjukkan bahwa adanya konsentrasi kepemilikan pihak luar menimbulkan pengaruh dari pihak luar sehingga mengubah pengelolaan perusahaan yang semula berjalan sesuai keinginan perusahaan itu sendiri menjadi memiliki keterbatasan (Sari, 2012).

Hasil penelitian ini menunjukkan terdapat arah negatif pada hubungan kepemilikan institusional dengan opini going concern. Widarjo et al. (2010) menjelaskan bahwa kondisi dimana institusi memiliki saham dalam suatu perusahaan. Institusi tersebut dapat berupa institusi pemerintah, institusi swasta, domestik maupun asing. Kepemilikan institusional dianggap lebih efektif dalam mengurangi masalah yang ditimbulkan karena teori keagenan, karena sebuah institusi dianggap lebih mampu dalam mengontrol manajemen dalam mengelola perusahaan melalui proses monitoring yang efektif. Kemudian pada penelitian Utami (2009) juga menjelaskan bahwa semakin besar kepemilikan institusional maka semakin efisien pemanfaatan aktiva perusahaan dan diharapkan juga dapat bertindak sebagai pencegahan terhadap pemborosan yang dilakukan oleh manajemen., Semakin besar presentase kepemilikan maka akan semakin besar dorongan untuk mengawasi manajemen dan kinerjanya sehingga dapat mengurangi potensi pemberian opini going concern oleh auditor.

\section{Pengaruh Proporsi Dewan Komisaris Independen (PDKI) terhadap Opini Going Concern(OGC)}

Berdasarkan pengujian yang telah dilakukan, hasil penelitian ini menunjukkan koefisien regresi positif sebesar 1,428 dengan tingkat signifikansi sebesar 0,372 (>0,05). Dengan demikian, hipotesis kedua (Ha2) tidak terdukung yang artinya kepemilikan institusional tidak berpengaruh signifikan terhadap opini going concern. Berdasarkan nilai odds ratio, probabilitas perusahaan yang memiliki kepemilikan institusional untuk mendapatkan opini going concern dari laporan opini yang dikeluarkan oleh auditor internal perusahaan adalah sebesar 95,707 dengan perusahaan yang memiliki rasio kepemilikan institusional lebih tinggi.

Hasil penelitian ini sejalan dengan penelitian Iskandar et al (2011) yang menunjukkan bahwa proporsi dewan komisaris independen tidak berpengaruh signifikan terhadap opini going concern. Peneliti 
menduga proporsi komisaris independen yang lebih besar mampu memberikan pengawasan yang lebih baik sehingga kemungkinan auditor memberikan opini going concern kecil. Semakin besar proporsi komisaris independen mampu mengurangi kemungkinan pemberian opini going concern (Setiawan,2011).

Hasil ini menunjukkan terdapat arah positif pada hubungan proporsi dewan komisaris independen terhadap opini going concern. Chandra (2012) menjelaskan bahwa berdasarkan Forum for Corporate Governance Indonesia (FCGI), dewan komisaris merupakan inti corporate governance yang ditugaskan untuk menjamin pelaksanaan strategi perusahaan, mengawasi manajemen dalam mengelola perusahaan serta mewajibkan terlaksananya akuntabilitas. Beberapa tugas dewan komisaris untuk mencegah munculnya going concern meliputi, monitoring penggunaan modal perusahaan, investasi dan penjualan aset, memonitor dan mengatasi masalah benturan kepentingan pada tingkat manajemen, anggota dewan direksi dan anggota dewan komisaris, termasuk penyalahgunaan aset perusahaan dan manipulasi transaksi perusahaan. Pada penelitian Klein (2002) dalam Wedari (2007) Struktur dewan yang independen terhadap CEO aktif dalam memonitor proses laporan akuntansi keuanganperusahaan.

\section{E. SIMPULAN DAN SARAN}

Berdasarkan hasil pengujian yang telah dilakukan , maka dapat diperoleh kepemilikan manajerial berpengaruh positif signifikan terhadap opini going concern kemudian untuk kepemilikan institusional dan proporsi dewan komisaris independen adalah negatif namun tidak signifikan.

Penelitian mengenai opini going concern dimasa yang akan datang diharapkan mampu memberikan hasil penelitian yang lebih berkualitas dengan mempertimbangkan saran seperti penelitian selanjutnya mungkin dapat memperluas sampel penelitian dengan menambahkan periodepengamatan, penelitian selanjutnya dapat menggunakan proksi lain untuk mengukur good corporate governance, seperti ukuran dewan komisaris, profitabilitas, komitte audit, serta menggunakan rasio return on equity(ROE), dan penelitian selanjutnya dapat mempertimbangkan beberapa variabel independen lain yang mungkin dapat mempengaruhi opini going concern, seperti karakteristik corporate governance dan komitteaudit.

\section{REFERENSI}

Belkaoui, Ahmed Riahi 2006. Teori Akuntansi, Edisi Kelima, Terjemahan AliAkbar Yulianto, Risnawati Dermauli, Salemba Empat,Jakarta.

Jensen, M.C. and W.H. Meckling. 1976. "Theory of the firm: Managerial Behavior, Agency Costs and Ownership structure.” Journal of Financial Economics 3, 305-360.

Brennan, Niamh; Solomon, J. (Jill). 2008. Corporate Governance, Accountability and Mechanisms of Accountability: An Overview. Accounting, Auditing, and Accountability Journal. 885-906.

Keputusan Direksi PT Bursa Efek Jakarta No Kep.315/BEJ/06-2000 tanggal 30 Juni 2000. Peraturan Pencatatan Efek Nomor 1-A : Tentang Ketentuan Umum Pencatatan Efek Bersifat Ekuitas di Bursa. Diakses pada 10 agustus 2017 dari www.birosdmkepri.com

Altman, E dan McGough, T. 1974. "Evaluation of A Company as A Going Concern". Journal of Accounting December. 50-57.

Rahmat Akbar Simamora, Hendarjatno. 2019. The Effects of Audit Client Tenure, Audit Lag, Opinion Shopping, Liquidity Ratio, and Leverage to The Going Concern Audit Opinion. Asian Journal of Accounting. Vol.4 No.1, hal 145- 156.

Kristina Deventy Eduk, Nugraen. 2015. Pengaruh Mekanisme Corporate Governance Terhadap Pemberian Opini Audit Going Concern Pada Perusahaan Manufaktur yang Terdaftar di BEI Tahun 2011-2013.

Jurnal Riset Akuntansi Mercu Buana. Vol.1 No.1, Hal 1-20.

Brillina Elita Mada, Herry Laksito. 2013. Pengaruh Mekanisme Corporate Governance, Reputasi KAP, 
Debt Default dan Financial Distress Terhadap Penerimaan Opini Audit Going Concern. Diponegoro Journal of Accounting. Vol.2 No.4, Hal 1-14.

Vidya Nurpratiwi, Shiddiq Nur Raharjo. 2014. Analisis Pengaruh Ukuran Perusahaan, Struktur Kepemilikan, Faktor Komite Audit, Rasio Profitabilitas, dan Rasio Aktivitas Terhadap Penerimaan Opini Audit Going Concern. Diponegoro Journal of Accounting. Vol.3 No.3, Hal 1-15.

Rivenski Atwinda Difa, Bambang Suryono. 2015. Pengaruh Keuangan, Kualitas Auditor, Kepemilikan Perusahaan Terhadap Penerimaan Opini Audit Going Concern. Jurnal Ilmu \& Riset Akuntansi. Vol.4 No.8, Hal-1-17.

Ravyanda, Endang, Siti. 2014. Pengaruh Komisaris Independen, Komite Audit dan Kepemilkan Institusional Terhadap Opini Audit Asumsi Going Concern. Jurnal Reviu Akuntansi dan Keuangan. Vol.4 No.2

Ahmad, Gede, Eka. 2017. Pengaruh Financial Distress, Perkara Pengadilan, dan Kepemilikan Manajerial Terhadap Penerimaan Opini Audit Going Concern. Jurnal Akuntansi Program S1 Akuntansi. Vol.8 No. 2. Hal 1-12.

Eka Cahyani, Nora Hilmia. 2017. Pengaruh Ukuran Kantoran Akuntan Publik, Komisaris Independen, Kepemilikan Institusional dan Audit Lag Terhadap Opini Audit Going Concern. Jurnal Akuntansi dan Keuangan. Vol.6 No.1. Hal 1-20.

Ainurrizky, Dewa. 2013. Pengaruh Opini Audit Going Concern, Kepemilikan Institusional dan Audit Delay Pada Voluntary Auditor Switching. Jurnal Akuntansi dan Keuangan. Vol.5 No.3, Hal 652-665.

Triani, Satyawan, Yanthi. 2017. Determining The Effectiveness of Going Concern Audit Opinion by ISA 570. Asian Journal of Accounting. Vol.2 No.2 Hal-29- 35.

Prita Andini, Anissa Amalia Mulya. 2015. Pengaruh Opini Audit Tahun Sebelumnya, Pertumbuhan Perusahaan, Proporsi Dewan Komisaris, Ukuran Komite Audit dan Debt Default Terhadap Opini Audit Going Concern pada Perusahaan Manufaktur yang Terdaftar di BEI Periode 2010-2014. Jurnal Akuntansi dan Keuangan. Vol.4 No.2, Hal-203-217.

Gallizo, Jose and Saladrigues. (2015) An analysis of determinants of going concern audit opinion: Evidence from Spain stock exchange. Intangible capital. 12(1).

Adjani, Ema Diandra, Surya Rahardja. 2013. Analisis Pengaruh Corporate Governance terhadap Kemungkinan Pemberian Opini Audit Going Concern oleh Perusahaan Manufaktur yang Terdaftar di BEI Tahun 2009-2011. Diponegoro Journal of Accounting. Vol.2 No.2, Hal 1-11.

Ramadhany, Alexandra. 2004. :Analisis Faktor-Faktor Yang Mempengaruhi Penerimaan Opini Going Concern pada Perusahaan Manufaktur yang Mengalami Financial Distress di Bursa Efek Jakarta". Tesis S2.Universitas Diponegoro.Semarang.

Ikatan Akuntansi Indonesia. 2007. Standar Profesional Akuntan Publik. Salemba Empat: Jakarta.

Nezky, Mita. 2013. Pengaruh Krisis Ekonomi Amerika Serikat Terhadap Bursa Saham dan Perdagangan Indonesia. Jurnal Ekonomi. Diakses pada 14 Agustus 2017 dari www.bi.go.id

Komite Nasional Kebijakan Governance (KNKG). 2006. Pedoman Umum Good Corporate Governance Indonesia. Jakarta. Diakses tanggal 12 Agustus 2017 dari www.knkg-indonesia.org

Kreditur PT Panghegar Putra Setujui Going Concern. Diakses pada 15 Mei 2017 dari www.kontan.co.id

PT Asia Natural Resource Tbk Delisting dari BEI. Diakses pada 10 Agustus 2014 dari www.finance.detik.com 